University of South Florida

DIGITAL COMMONS

Digital Commons @ University of

@ UNIVERSITY OF SOUTH FLORIDA

South Florida

USF Accountability Reports

USF Archives

$1-1-2010$

\title{
2010 Annual Report USF St. Petersburg
}

USF

Follow this and additional works at: https://digitalcommons.usf.edu/usf_accountability_reports

\section{Scholar Commons Citation}

USF, "2010 Annual Report USF St. Petersburg" (2010). USF Accountability Reports. 8.

https://digitalcommons.usf.edu/usf_accountability_reports/8

This Article is brought to you for free and open access by the USF Archives at Digital Commons @ University of South Florida. It has been accepted for inclusion in USF Accountability Reports by an authorized administrator of Digital Commons @ University of South Florida. For more information, please contact digitalcommons@usf.edu. 


\section{University of South Florida--St. Petersburg}

Approved by the USF System BOT, December 16th, 2010 


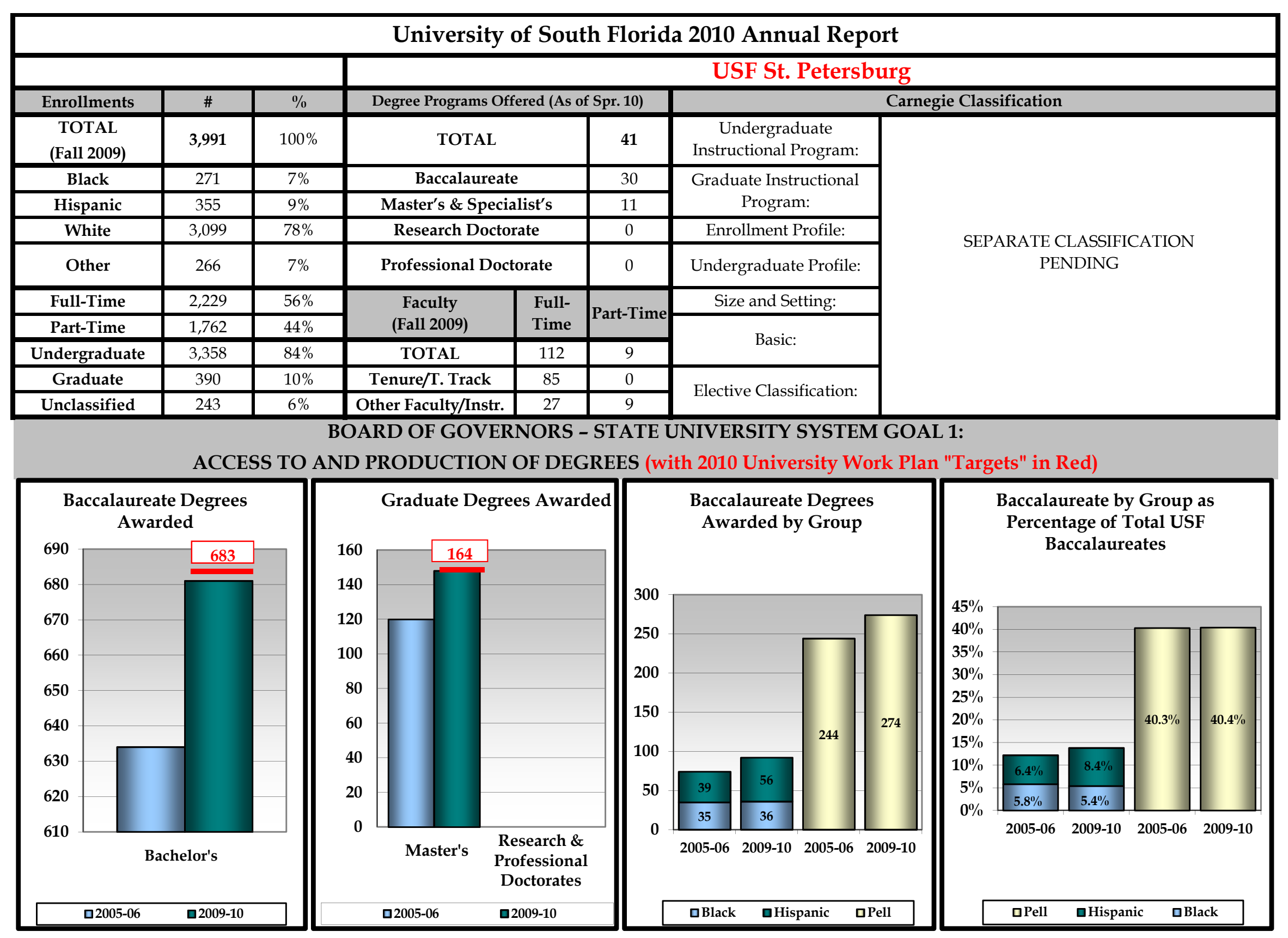

2012 - 2013 Projected Institutional Contributions in RED PRINT. 
BOARD OF GOVERNORS - STATE UNIVERSITY SYSTEM GOAL 2:

MEETING STATEWIDE PROFESSIONAL AND WORKFORCE NEEDS (with 2010 University Work Plan "Targets" in Red)

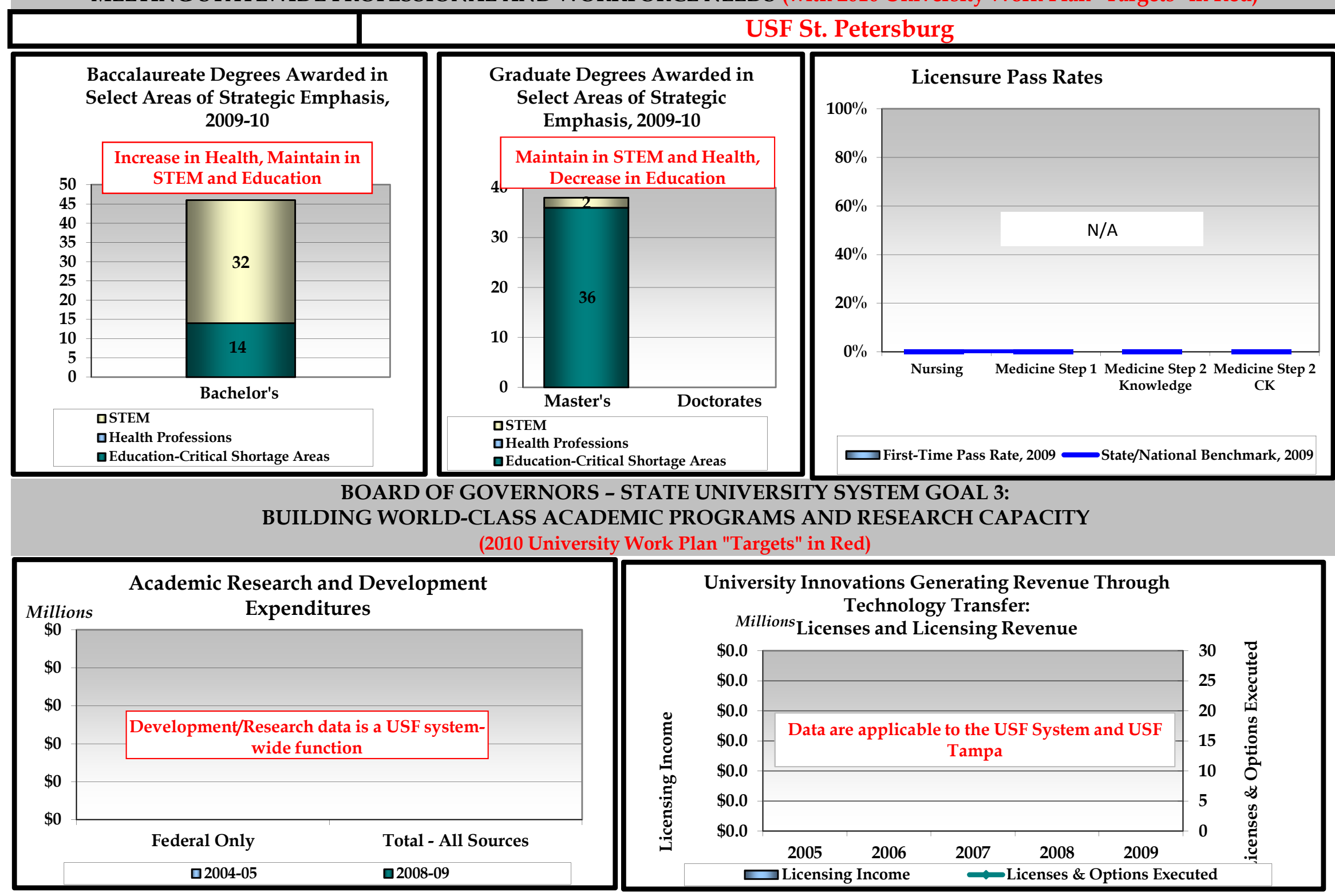

Projected Institutional Contributions in RED PRINT

(2012 - 2013 for TOTAL Degrees in Areas of Strategic Emphasis; 2012 for NCLEX; 2011 -2012 for R\&D, Licences, and Licensing Revenue). 


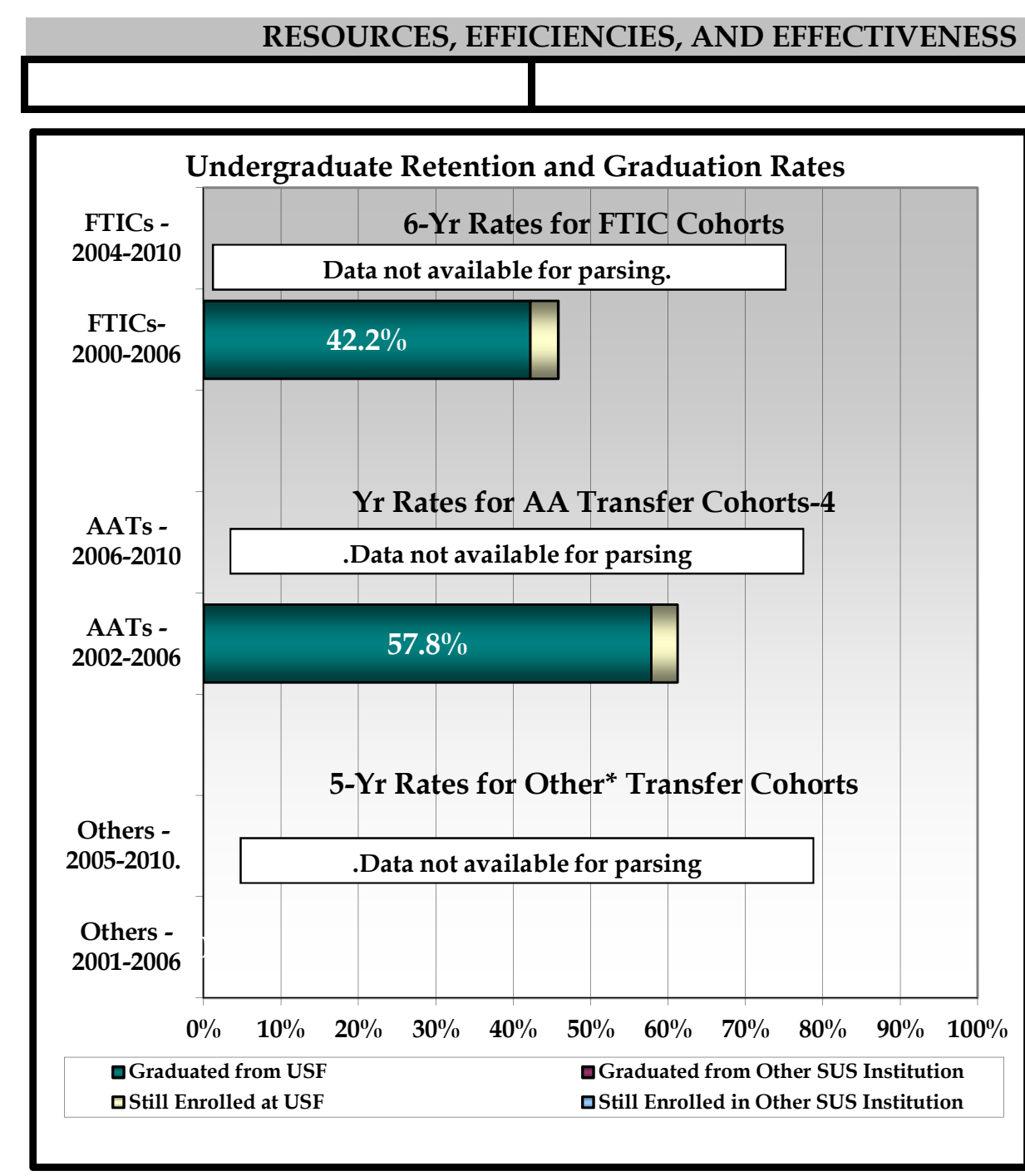

* The composition of "Other Transfer" cohorts may vary greatly by institution and by year.

\section{USF St. Petersburg}

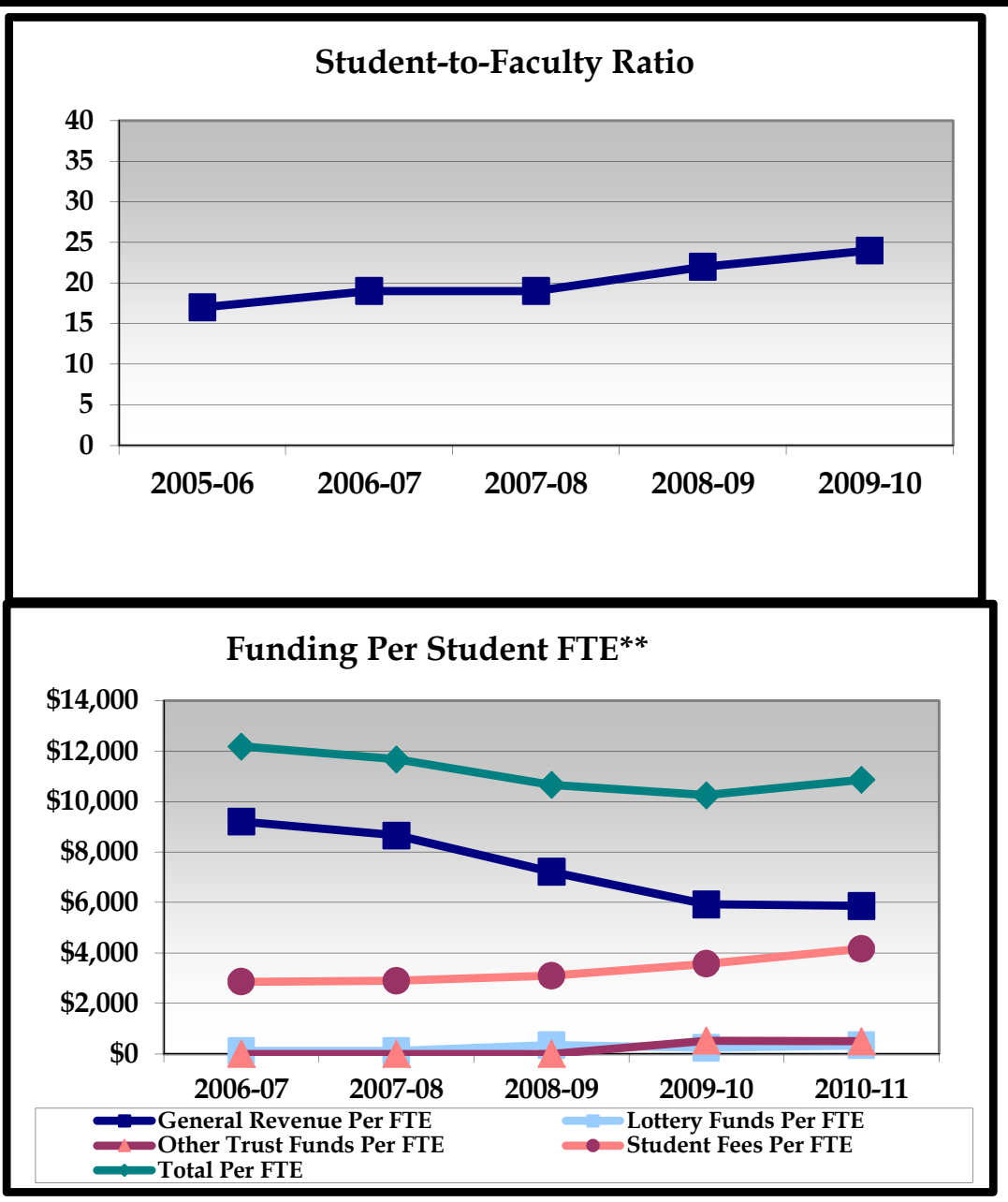

** FTE for this metric uses the standard IPEDS definition of FTE, equal to 30 credit hours for undergraduates and 24 for graduates.

Graduation Rate from SAME Institution - Projected Institutional Contributions in RED PRINT. 


\section{Key University Achievements}

Note: Limit to one-page. Enter a maximum of three issues per category. Only use 11-point Book Antiqua font.

\section{Student awards/achievements}

1. Debate team recognized as "Best New Team" nationally by Cross Examination Debate Association, and team president David Trigaux was named an AllAmerican Debater by the Association.

2. Sailing team nationally ranked in the Top 15 by NCAA

3. Kira Barrera, a junior Environmental Science and Policy major, received a prestigious Hollings Scholarship from the National Oceanic and Atmospheric Administration.

\section{Faculty awards/achievements}

1. Fulbright award to Dr. Judithanne Scourfield McLauchlan for study of governmental institutions in Moldova

2. Dr. Raymond Arsenault's book, "Freedom Riders" produced as part of the PBS Series, The American Experience

\section{- Program awards/achievements}

1. Journalism and Media Studies programs (graduate and undergraduate) successfully reaccredited by the Accrediting Council for Education in Journalism and Mass Communications.
2. College of Education successfully accredited by National Council for Accreditation of Teacher Education.

\section{- Research awards/achievements}

1. TRIO Student Success Award from the US Department of Education (one of very few new such awards nationally)

2. Number of undergraduate research presentations/ posters increased more than 600 percent from 33 (2008-09) to 221 (2009-10)

\section{Institutional awards/achievements}

1. The university's Academic Success Center was certified by the College Reading and Learning Association, one of only three such certified centers at SUS institutions.

2. Completed and successfully submitted the rigorous application for the Carnegie Elective Classification for the "Civically Engaged University"

3. Science and Technology Building achieved LEED Gold Certification 


\section{INTRODUCTION}

University of South Florida, St. Petersburg

The University of South Florida St. Petersburg (USFSP) was first accredited in 2006. It is now and will continue to be a member of the University of South Florida system of institutions which include USF Tampa, USF Sarasota/Manatee and USF Polytechnic (both now seeking separate accreditation). Over the past four years, USFSP has strengthened both its academic and its research profile. The opening of a residence hall for students in fall 2006 represented a milestone in the realization of the institution's Strategic Plan. The current Strategic Plan includes a Multipurpose Campus Center that provides additional residential spaces, addresses the growth in FTIC enrollment and a concomitant increase in student organizations, oncampus student life activities, and the need for enhanced student support services. USFSP is on a path to realize its vision as a Masters level comprehensive university serving regional needs yet supporting the broader USF System goals.

\section{BOARD OF GOVERNORS - STATE UNIVERSITY SYSTEM GOAL 1: ACCESS TO AND PRODUCTION OF DEGREES}

USF St. Petersburg's enrollments have been steadily growing over the past four years, from a total of 3.606 home campus $/ 5,305$ funding campus (final headcount) students in Fall 2007 to 4,015 home campus/6,020 funding campus (preliminary headcount) students in Fall 2010, a 12 percent increase in home campus and a 13.5 percent increase in funding campus headcounts. The array of degree program offerings, both at the undergraduate and graduate level have been selected and refined to reflect regional needs and to complement those at other USF System member institutions. USFSP offers a robust academic environment for transfer students although the growth of the state college system has been a challenge to recruitment for this group of students. Baccalaureate degree production has been steady with 668 baccalaureate degrees awarded in AY2007-08 and 681 awarded in AY 2009-2010. Enrollment in graduate programs has held steady which is an accomplishment given the deteriorating economic conditions over the past two years. Graduate (Masters) degree production has increased, with 120 degrees awarded in AY2007-08 and 148 awarded in AY200910.

The ethnic and racial demographic profile of USFSP students generally reflects the population of Pinellas County. USFSP's academic environment benefits students from all demographic groups due to its relatively small classes (in 2008-09 nearly 90 percent of all class sections were less than 50 students) and the commitment of faculty and staff to student success and to providing students with outstanding service in all educational and academic support areas.

\section{BOARD OF GOVERNORS - STATE UNIVERSITY SYSTEM GOAL 2: MEETING STATEWIDE PROFESSIONAL AND WORKFORCE NEEDS}

USF St. Petersburg is focused on meeting both regional and statewide professional and workforce needs. It accomplishes this goal by offering degree programs that address high-need

Approved by the USF System Board of Trustees, December $16^{\text {th }}, 2010$ 
areas within Florida's workforce. For example, the College of Education which is fully accredited by the National Council for the Accreditation of Teacher Education (NCATE) revised and refined its undergraduate degree offerings specifically in response to the need of local school districts for elementary school teachers who are qualified to teach every child, including exceptional needs children and children whose first language is not English. The B.S. degree (restructured in 2009) will enable graduates to be highly flexible in their employment. It will also give principals and superintendents high confidence that USFSP graduates are well-equipped for success in many educational settings.

The College of Arts and Sciences and the College of Education have partnered to offer a Professional Training Option to provide students who are majoring in other areas besides education to take a series of courses that will enable them to qualify for initial teacher certification in the State of Florida. This program gives students additional flexibility in postbaccalaureate study or career choices.

Two new degree programs approved in 2010 by the USF System Board of Trustees, the B.S. in Health Sciences and the B.S. in Entrepreneurship, specifically address regional needs for professionals in a wide range of health-related areas and for graduates who both understand the entrepreneurial business environment and have the skills to contribute to it.

The College of Business, which is fully accredited in both business and accounting by the Association to Advance Collegiate Schools of Business - International (AACSB), offers a distinctive milieu in which business education is placed. The
College has a special focus on corporate and social responsibility, that is, the ethical and responsible conduct of business. The College has been consistently ranked in the top 50 institutions in the nation for its achievements in this area. USFSP graduates in both business and accounting are sought after by Florida firms since this ethos of corporate and social responsibility is highly valued and few institutions make it a focus of their programs.

The Department of Journalism and Media Studies within the College of Arts and Sciences is fully accredited by the Accrediting Council on Education in Journalism and Mass Communications (ACEJMC) has been cited by the organization for its forward-looking curriculum and dedication to student success.

\section{BOARD OF GOVERNORS - STATE UNIVERSITY SYSTEM GOAL 3: BUILDING WORLD-CLASS ACADEMIC PROGRAMS AND RESEARCH CAPACITY}

USFSP has built and is building outstanding academic programs and is expanding research capacity in keeping with its mission.

For example:

- The College of Business was ranked \#36 in the world in the Global 100 ranking of the Aspen Institute's "Beyond Gray Pinstripes" which is based on the strength of an institution's programs in corporate and social responsibility. 
- The College of Education received full accreditation for all programs by the National Council of Teacher Accreditation (NCATE) in 2010.

- The Department of Journalism and Media Studies (College of Arts and Sciences) achieved re-accreditation through the Accrediting Council on Education in Journalism and Mass Communication in 2010, one of only 114 such accredited programs in the US.

- The College of Education implemented a unique undergraduate degree, the B.S. in Education, that provides graduates with licensure in elementary education and exceptional student education as well as state-approved endorsements for reading and ESOL.

- The College of Education, in partnership with SRI International and the Pinellas County School District, has developed a path-breaking, nationally recognized program for more effective approaches to teaching algebra and geometry in middle school using digital technology. As a result, the university was able to offer a graduate certificate in Digital Mathematics to area middle school teachers.

- USFSP has greatly expanded and strengthened its focus on undergraduate research with faculty. Undergraduate research has been shown to be a key element in placing students in premier graduate programs and it has also been shown to improve both student academic performance and persistence. A new electronic student research journal will be launched in 2010.

- Many USFSP faculty are recognized around the nation and the world as leading scholars in their fields:

- Dr. Ray Arsenault has been recognized for his work on the civil rights movement and has had his most recent book, "Freedom Riders," produced by PBS as part of the "American Experience" series.

- Dr. Lyman Dukes is a well-known innovator in education of exceptional needs children and was awarded major funding by the Florida Department of Education to implement a program designated as a statewide model.

- Dr. Mark Durand is a highly regarded scholar in the field of autism and a prolific textbook author.

- Dr. Malcolm Butler is a nationally-recognized scholar in science education and well-known for his work to increase the numbers of African Americans entering STEM fields.

- Drs. John and Kathryn Arthur are nationally-known scholars in anthropology with support from the National Science Foundation for their work in Ethiopia.

- Dr. James McHale has major funding from the National Institute of Child Health and Development for his work with parents and infants in difficult family situations.

\section{BOARD OF GOVERNORS - STATE UNIVERSITY SYSTEM GOAL 4: MEETING COMMUNITY NEEDS AND FULFILLING UNIQUE INSTITUTIONAL RESPONSIBILITIES}

The University of South Florida St. Petersburg reflects its commitment to meeting community needs and fulfilling unique institutional responsibilities in its mission statement and strategic goals. 
- USFSP's Center for Civic Engagement (CCE), founded in 2006, catalyzed and funded curricular innovations that focus on civic scholarship and has itself been responsible for contributing nearly 238,000 hours to local and regional community organizations with an estimated value of more than $\$ 4.5$ million since its founding.

- USFSP completed the rigorous application process for the Carnegie Corporation's Elective Classification as a "Civically Engaged University".

- USFSP (Department of Journalism and Media Studies) was one of only 10 universities nationwide, and the only university in Florida, to host a delegation of visiting foreign journalists sponsored by the U.S. Department of State (Edward R. Murrow Program).

- USFSP was one of only a handful of institutions in the nation to receive a new TRIO Student Support Services grant from the US Department of Education. This 5-year grant, which will serve 200 students per year, focuses on student success for First Generation/Low Socioeconomic Status FTIC students and provides support services, mentoring, tutoring and other strategies to increase the graduation rate for this group of undergraduates. Many of the TRIO students will be drawn from those who live in the local area.

- USFSP is host to Project STING RAY, a designated statewide model program funded by the Florida Department of Education to increase access to higher education for persons with intellectual disabilities. USFSP is partnering with the Pinellas County School Board to enable students from the County to experience life on a college campus including auditing selected classes and interacting with undergraduate student mentors.

- The university expanded its partnerships in the community through the Lead-Learn Serve (LLS) program that is funded by a three year $\$ 400,000$ Learn and Serve America grant from the Corporation for National and Community Service. USFSP offered $\$ 5000$ grants to local non-profits through 10 Student Philanthropy Boards. The Student Philanthropy Boards received 65 proposals from over 60 Tampa Bay nonprofits. Examples of awards include:

$\circ$ The Boys and Girls Club of the Suncoast Region: Be Great mentoring program

- Directions for Mental Health: Transportation assistance to homeless people who need medical and mental health services

$\circ$ The Haven of RCS: Computer access and training to survivors of domestic violence

○ Police Athletic League: An organic garden and educational program that encourages environmental stewardship and sustainability while promoting healthy nutrition and combating youth obesity.

o Sistah2Sistah (Golden Generation Inc.): An academic, social and personal enrichment program for middle school girls in Midtown.

- The university continues to grow partnerships with local non-profits by developing training opportunities. The LLS program coordinated workshops and training for the regional community which included non-profit Dialogues, the Margaret Wheatley Leadership Symposium, a Community Needs Assessment 
Workshop/Training, a Nonprofit Grant Award Ceremony and Training, and a Non-Profit Training: "Marketing and Media".

- The College of Business provided a report, "Economic Impact of Arts and Culture in St Petersburg" to the Arts Council of St Petersburg and the City of St. Petersburg. The analysis showed that arts and cultural organizations contribute over \$20 million to the city's economy while providing over 500 jobs.

- College of Business students provided assistance to low and moderate income taxpayers through the IRS Volunteer Income Tax Assistance (VITA) Program. During the Spring 2010 tax season, over 1,000 tax returns were prepared by the students, generating nearly $\$ 1,000,000$ in tax refunds for Pinellas County families.

\section{PROGRESS ON PRIMARY INSTITUTIONAL GOALS AND METRICS AS OUTLINED IN THE UNIVERSITY WORK PLAN}

Goal 1. Enhance learning and achievement and promote student retention through curricular and co-curricular programs (continuing).

Metrics; Retention rate year to year; $4 / 5 / 6$ year graduation rate; ratio of academic advisors to students; number of D/F/W grades in key entry level courses (College Algebra, English Composition); number of students accepted to/enrolled in post-baccalaureate training or employed within one year of graduation; increased student satisfaction with academic advising.

\section{Progress to date (2009-10):}

- One full-time additional academic advisor has been hired and another position is in the final stages of being selected for a total of 9 advisors for about 3,900 students. When this hire is completed, this will reduce the USFSP student:advisor ratio to about 430:1 from 487:1, very near the goal of 425:1. In addition, one new staff member will be hired within the next few weeks to enable the office to maintain extended hours to serve more students.

- Completion of the Quality Enhancement Plan (QEP) focused on enhanced student learning in key "gateway" mathematics courses is on schedule for December 2011. This Plan is required by the Southern Association of Colleges and Schools. A QEP Director is being sought now and is expected to be hired prior to the On-Site Review Team accreditation visit in February, 2011. The QEP focuses specifically on a student success model that is intended to reduce the percentage of students with D/F/W grades in three "gateway" courses: College Algebra, Finite Mathematics, and Elementary Statistics.

- Two searches for new faculty in key science disciplines have been approved and are underway. This is intended to strengthen course offerings in the sciences which will assist students in being more competitive for postbaccalaureate training and/or employment. The faculty to student ratio at USFSP is $24: 1$, compared to a USF System wide average of 27:1.

- Four additional tutor positions have been approved for hiring. 
Goal 2: Increase faculty and student research and creative activities (continuing).

Metrics: Total amount of externally funded research/sponsored programs annually; number of large awards (over $\$ 100,000$ ) annually; number of proposals written; percentage of proposals awarded; number of publications in peer-refereed journals/books/monographs; number of faculty publications with student (graduate or undergraduate) coauthors; number of student presentations at local/regional/national/international conferences; number of proposal/awards and/or publications with non-USFSP coauthors/co-investigators.

\section{Progress to date (2009-10):}

- Total amount of externally funded research/ sponsored programs rose over 20 percent from $\$ 1.7$ million in 2008-09 to \$2.1 million in 2009-10.

- Number of large awards (over $\$ 100,000$ ) rose from 1 in 2008-09 to 4 in 2009-10.

- A Student research journal (electronic) is "under construction"

- Number of student research/creative presentations during USFSP research month rose dramatically from 33 in 2008-09 to 221 in 2009-10. This reflects USFSP's increased investment in support for undergraduate research and creative activities.

- Faculty peer-refereed publications rose by 16 percent to 79 in 2009-10. This is noteworthy in the face of significant budget reductions and increased workloads.

Goal 3: Initiate Construction of the Multipurpose Campus Center

Metrics: Enhanced student satisfaction through surveys such as NSSE and CIRP; greater numbers of student organizations and measurement of the impact of these organizations on campus life and the community (through surveys of entities such as the St. Petersburg Downtown Partnership); enhanced revenues from residential occupancy and dining.

Progress to date (2009-10):

- Legislation approved by Florida Legislature to raise fee cap

- Student fee increase approved for this facility and is now being collected (as of Fall 2010 semester)

- Financial Plan for the facility approved by the USF Board of Trustees.

- The Financial plan has now been submitted to the SUS/BOG

\section{ADDITIONAL INFORMATION ON QUALITY, RESOURCES, EFFICIENCIES, AND EFFECTIVENESS}

The University of South Florida St. Petersburg has been challenged as never before by the statewide budget and economic crisis. This challenge has resulted in actions to reengineer many of its processes and reorganize its administrative functions to increase efficiency and deliver 
outstanding student services with reduced resources. For example, Academic Affairs and Student Affairs realigned admissions, financial aid, registration and records, and student academic support (tutoring center) functions to enable better service to more students with fewer people.

International affairs was reassigned to a staff member in Academic Affairs following the announced retirement of the interim director. The Quality Enhancement Plan (QEP) Director will also take on the role of Director of the Academic Success Center so that the functions can be effectively integrated and provide needed synergies for the QEP.

USFSP reduced its leasing costs for space by moving a large number of personnel from leased space to university-owned space. USFSP has reduced its energy consumption $11 \%$ since 2007 resulting in a savings of nearly $\$ 200,000$. This has been accomplished through nighttime setback of HVAC ; increasing the cooling set point and decreasing the heating set point on thermometers in all offices, classrooms and common areas; installing motion sensors on lights where feasible; installing solar reflective film on windows; and reducing lighting where feasible. USFSP has also accomplished personnel efficiencies in administrative areas. For example, Parking and Purchasing functions were consolidated into one position; facilities planning and facilities maintenance functions were combined into a single department; and cross-training of cashiers, purchasing and parking staff has resulted in more efficient operations. In addition, environmentally friendly practices such as greatly reduced paper consumption, and conversion to eco-friendly cleaning products and maintenance have resulted in more effective operations consistent with USFSP's strategic goal of environmental stewardship.

\section{ADDITIONAL RESOURCES}

Institutional Research Office:

www.stpete.usf.edu/ir

Strategic Planning Website:

www.stpete.usf.edu/strategicplanning

USFSP Peer Institutions:

www.stpete.usf.edu/strategicplanning 


\section{Section 1 - Financial Resources (including Health-Science Center \& IFAS, if applicable)}

Table 1A. Education and General Revenues

Table 1B. Education and General Expenditures

Table 1C. Funding per Student

Table 1D. Other Budget Entities

Table 1E. Total Revenues and Expenditures

Table 1F. Voluntary Support of Higher Education

Table 1G. Federal Stimulus Dollars (ARRA)

\section{Section 2 - Personnel}

Table 2A. Personnel Headcount

\section{Section 3 - Enrollment \& Space}

Table 3A. University Full-time Enrollment (FTE)

Table 3B. Enrollment by Location

Table 3C. Space Utilization

\section{Section 4 - Undergraduate Education}

Table 4A. Baccalaureate Degree Program Changes in AY 2009-2010

Table 4B. $\quad$ First-Year Persistence Rates

Table 4C. Federal Definition - Undergraduate Progression and Graduation Rates

for Full-time First-time-in-College (FTIC) Students

Table 4D. SUS - Undergraduate Progression and Graduation Rates

for First-time-in-College (FTIC) Students

Table 4E. SUS - Undergraduate Progression and Graduation Rates for AA Transfer Students

Table 4F. $\quad$ SUS - Undergraduate Progression and Graduation Rates

$$
\text { for Other Transfer Students }
$$

Table 4G. Baccalaureate Degrees Awarded

Table 4H. Baccalaureate Degrees Awarded in Areas of Strategic Emphasis

Table 4I. Baccalaureate Degrees Awarded to Underrepresented Groups

Table 4J. Baccalaureate Completion Without Excess Credit Hours

Table 4K. Undergraduate Course Offerings

Table 4L. Faculty Teaching Undergraduates

Table 4M. Undergraduate Instructional Faculty Compensation

Table 4 N. Student/Faculty Ratio

Table 4O. Licensure Pass Rates

Table 4P. Tuition Differential Fee

\section{Section 5 - Graduate Education}

Table 5A. Graduate Degree Programs Changes in AY 2009-2010

Table 5B. Graduate Degrees Awarded

Table 5C. Graduate Degrees Awarded in Areas of Strategic Emphasis

Table 5D. Licensure Pass Rates

\section{Section 6 - Research and Economic Development}

Table 6A. Research and Development

Table 6B. Centers of Excellence

Table 6C. State University Research Commercialization Assistance Grants

Table 6D. 21st Century World Class Scholars Program

\section{Appendix I - Definitions}


STATE UNIVERSITY SYSTEM - 2010 ANNUAL REPORT

Section 1 - Financial Resources

University of South Florida--St. Petersburg

Table 1A. University Education and General Revenues

\begin{tabular}{|c|c|c|c|c|c|}
\hline & $\begin{array}{l}2006-07 \\
\text { Actual }\end{array}$ & $\begin{array}{c}2007-08 \\
\text { Actual }\end{array}$ & $\begin{array}{l}2008-09 \\
\text { Actual }\end{array}$ & $\begin{array}{c}2009-10 \\
\text { Actual }\end{array}$ & $\begin{array}{c}\text { 2010-11 } \\
\text { Estimates }\end{array}$ \\
\hline $\begin{array}{l}\text { Recurring State Funds } \\
\text { (GR \& Lottery) }\end{array}$ & $\$ 28,243,738$ & $\$ 27,700,768$ & $\$ 25,774,396$ & $\$ 22,545,822$ & $\$ 22,626,763$ \\
\hline $\begin{array}{l}\text { Non-Recurring State Funds } \\
\text { (GR \& Lottery) }\end{array}$ & $\$ 0$ & $\$ 675,721$ & $\$ 279,190$ & $\$ 162,435$ & $\$ 177,904$ \\
\hline $\begin{array}{c}\text { Tuition } \\
\text { (Resident/Non-Resident) }\end{array}$ & $\$ 8,370,447$ & $\$ 9,367,715$ & $\$ 10,665,205$ & $\$ 12,477,913$ & $\$ 15,480,500$ \\
\hline Tuition Differential Fee & $\$ 0$ & $\$ 0$ & $\$ 0$ & $\$ 409,066$ & $\$ 1,010,274$ \\
\hline $\begin{array}{c}\text { Other Revenues } \\
\text { (Includes Misc. Fees E Fines) }\end{array}$ & $\$ 287,117$ & $\$ 11,317$ & $\$ 12,584$ & $\$ 256,990$ & $\$ 215,960$ \\
\hline $\begin{array}{c}\text { Phosphate Research } \\
\text { Trust Fund } \\
\end{array}$ & $\$ 0$ & $\$ 0$ & $\$ 0$ & $\$ 0$ & $\$ 0$ \\
\hline Federal Stimulus Funds & $\$ 0$ & $\$ 0$ & $\$ 0$ & $\$ 1,925,121$ & $\$ 1,842,058$ \\
\hline TOTAL & $\$ 36,901,302$ & $\$ 37,755,521$ & $\$ 36,731,375$ & $\$ 37,777,347$ & $\$ 41,353,459$ \\
\hline
\end{tabular}

*Note: 2010-11 estimates for the USF System report are accepted at the request of the BOG. It should be noted however, that a discrepancy in the amount of transfers between the main campus and HSC is reflected in this table and in the HSC corresponding table. In turn, the individual campus reports will not roll up to these reflected totals and will corrections will be reflected in the 2011 Annual Report.

\begin{tabular}{|c|c|c|c|c|c|}
\hline & $\begin{array}{r}2006-07 \\
\text { Actual } \\
\end{array}$ & $\begin{array}{r}\text { 2007-08 } \\
\text { Actual }\end{array}$ & $\begin{array}{r}2008-09 \\
\text { Actual }\end{array}$ & $\begin{array}{r}\text { 2009-10 } \\
\text { Actual } \\
\end{array}$ & $\begin{array}{c}2010-11 \\
\text { Estimates }\end{array}$ \\
\hline Instruction/Research & $\$ 22,789,808$ & $\$ 22,701,438$ & $\$ 20,321,741$ & $\$ 20,220,884$ & $\$ 29,343,548$ \\
\hline Institutes and Research Centers & $\$ 0$ & $\$ 0$ & $\$ 0$ & $\$ 0$ & $\$ 0$ \\
\hline PO\&M & $\$ 4,181,799$ & $\$ 3,879,638$ & $\$ 3,259,211$ & $\$ 4,239,436$ & $\$ 4,344,504$ \\
\hline $\begin{array}{c}\text { Administration } \\
\text { and Support Services }\end{array}$ & $\$ 3,210,955$ & $\$ 3,213,225$ & $\$ 3,242,984$ & $\$ 3,313,581$ & $\$ 3,356,866$ \\
\hline Radio/TV & $\$ 0$ & $\$ 0$ & $\$ 0$ & $\$ 0$ & $\$ 0$ \\
\hline Library/Audio Visual & $\$ 1,651,300$ & $\$ 1,372,585$ & $\$ 1,233,804$ & $\$ 1,252,316$ & $\$ 1,604,747$ \\
\hline Museums and Galleries & $\$ 0$ & $\$ 0$ & $\$ 0$ & $\$ 0$ & $\$ 0$ \\
\hline Agricultural Extension & $\$ 0$ & $\$ 0$ & $\$ 0$ & $\$ 0$ & $\$ 0$ \\
\hline Allied Clinics & $\$ 0$ & $\$ 0$ & $\$ 0$ & $\$ 0$ & $\$ 0$ \\
\hline Student Services & $\$ 1,036,753$ & $\$ 1,053,402$ & $\$ 1,501,357$ & $\$ 1,418,035$ & $\$ 1,306,026$ \\
\hline Intercollegiate Athletics & $\$ 0$ & $\$ 0$ & $\$ 0$ & $\$ 0$ & $\$ 0$ \\
\hline TOTAL & $\$ 32,870,615$ & $\$ 32,220,288$ & $\$ 29,559,097$ & $\$ 30,444,252$ & $\$ 39,955,691$ \\
\hline
\end{tabular}


The table reports the actual and estimated amount of expenditures from revenues appropriated by the legislature for each fiscal year. The expenditures are classified by Program Component (i.e., Instruction/Research, PO\&M, Administration, etc...) for activities directly related to instruction, research and public service. The table does not include expenditures classified as non-operating expenditures (i.e., to service asset-related debts), and therefore excludes a small portion of the amount appropriated each year by the legislature. Also, the table does not include expenditures from funds carried forward from previous years. 


\begin{tabular}{|c|c|c|c|c|c|}
\hline \multicolumn{6}{|c|}{$\begin{array}{l}\text { STATE UNIVERSITY SYSTEM - } 2010 \text { ANNUAL REPORT } \\
\text { Section } 1 \text { - Financial Resources }\end{array}$} \\
\hline \multicolumn{6}{|c|}{ University of South Florida--St. Petersburg } \\
\hline \multicolumn{6}{|c|}{ Table 1C. Funding per Full-Time Equivalent (FTE) Student } \\
\hline & 2006-07 & 2007-08 & 2008-09 & 2009-10 & 2010-11 \\
\hline \multicolumn{6}{|l|}{ Appropriated Funding per FTE } \\
\hline General Revenue per FTE & $\$ 9,210$ & $\$ 8,661$ & $\$ 7,219$ & $\$ 5,926$ & $\$ 5,860$ \\
\hline Lottery Funds per FTE & $\$ 119$ & $\$ 116$ & $\$ 343$ & $\$ 238$ & $\$ 339$ \\
\hline $\begin{array}{l}\text { Tuition \& Fees per FTE } \\
\text { (based on Budget Authority) }\end{array}$ & $\$ 2,859$ & $\$ 2,901$ & $\$ 3,100$ & $\$ 3,568$ & $\$ 4,161$ \\
\hline Other Trust Funds per FTE & $\$ 0$ & $\$ 0$ & $\$ 0$ & $\$ 523$ & $\$ 501$ \\
\hline Total per FTE & $\$ 12,188$ & $\$ 11,678$ & $\$ 10,662$ & $\$ 10,255$ & $\$ 10,861$ \\
\hline Actual Funding per FTE & 2006-07 & $2007-08$ & 2008-09 & $2009-10$ & est. 2010-11 \\
\hline $\begin{array}{l}\text { Tuition \& Fees per FTE } \\
\text { (based on Actual Collections) }\end{array}$ & $\$ 2,859$ & $\$ 2,901$ & $\$ 3,100$ & $\$ 3,568$ & $\$ 4,541$ \\
\hline Actual Total per FTE & $\$ 12,188$ & $\$ 11,678$ & $\$ 10,662$ & $\$ 10,255$ & $\$ 11,241$ \\
\hline
\end{tabular}

*Note: Change to reporting of these data on funding per student FTE may result in differences in years prior to $2009-10$ as history was not modified to reflect the new reporting methodology.

**Note: Figures are approved for the 2010 Annual Report but it should be noted however,discrepancies due to transfers not reflected in this report may result; figures will be corrected in the following annual report.

Notes: (1) FTE is based on actual FTE, not funded FTE; (2) Does not include Health-Science Center funds or FTE; (3) FTE for these metrics uses the standard IPEDS definition of FTE, equal to 30 credit hours for undergraduates and 24 for graduates; and (4) Actual funding per student is based on actual tuition and E\&G fees (does not include local fees) collected.

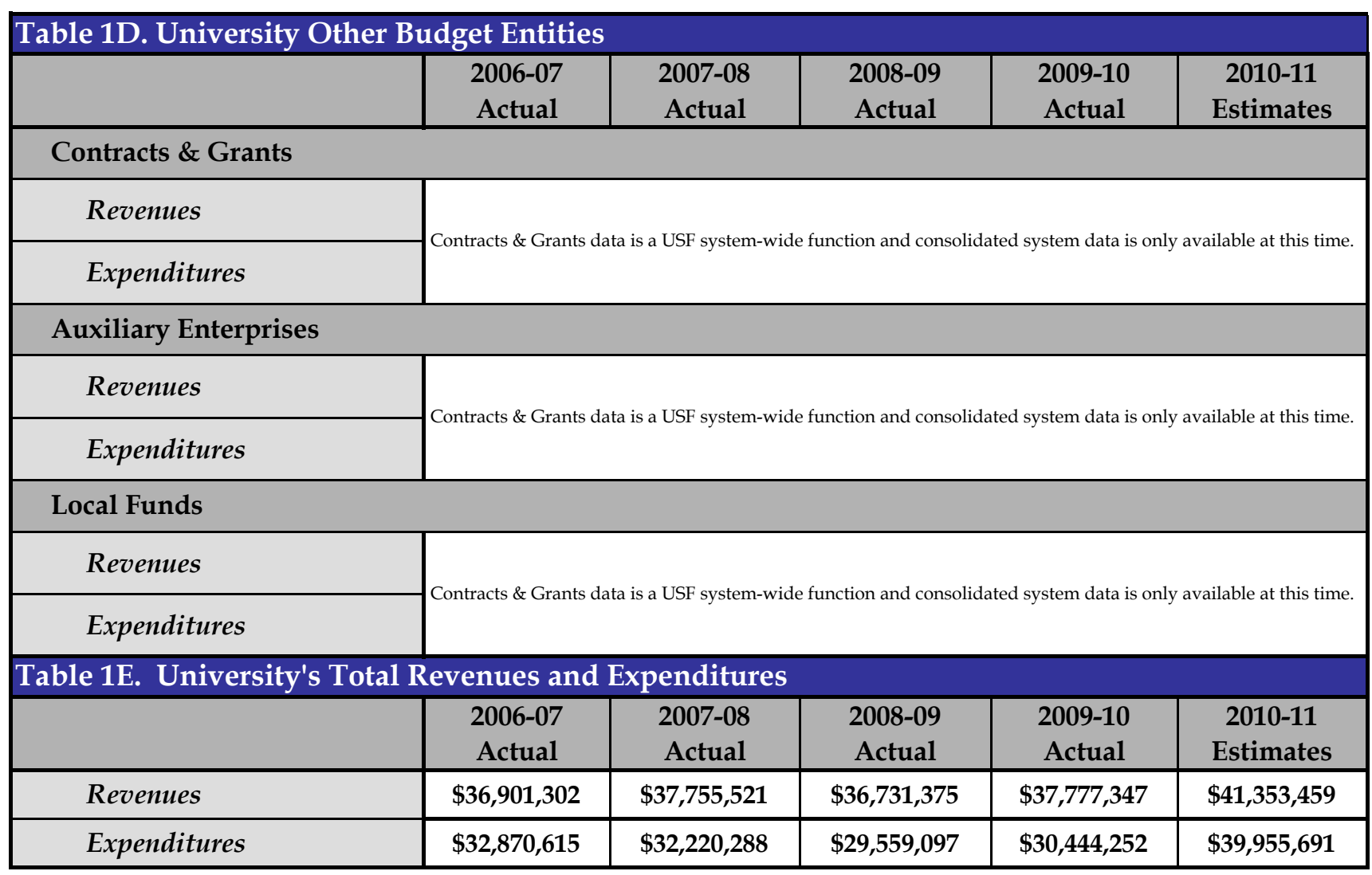


*Note: 2010-11 estimates for the USF System report are accepted at the request of the BOG. It should be noted however, that a discrepancy in the amount of transfers between the main campus and HSC is reflected in this table and in the HSC corresponding table. In turn, the individual campus reports will not roll up to these reflected totals and will corrections will be reflected in the 2011 Annual Report. 


\begin{tabular}{|c|c|c|c|c|c|}
\hline \multicolumn{6}{|c|}{$\begin{array}{l}\text { STATE UNIVERSITY SYSTEM - } 2010 \text { ANNUAL REPORT } \\
\text { Section } 1 \text { - Financial Resources }\end{array}$} \\
\hline \multicolumn{6}{|c|}{ University of South Florida--St. Petersburg } \\
\hline \multicolumn{6}{|c|}{ Table 1F. Voluntary Support of Higher Education } \\
\hline & 2004-2005 & $2005-2006$ & 2006-2007 & $2007-2008$ & 2008-2009 \\
\hline $\begin{array}{l}\text { Endowment Market Value } \\
\text { (Thousand \$) }\end{array}$ & \multirow{3}{*}{\multicolumn{5}{|c|}{$\begin{array}{l}\text { Development/Research data is a USF system-wide function. Consolidated system } \\
\text { data is only available at this time. }\end{array}$}} \\
\hline $\begin{array}{l}\text { Annual Gifts Received } \\
(\$)\end{array}$ & & & & & \\
\hline $\begin{array}{l}\text { Percentage of Graduates Who } \\
\text { Are Alumni Donors }\end{array}$ & & & & & \\
\hline
\end{tabular}

\begin{tabular}{|l|c|c|}
\hline Table 1G. University Federal Stimulus Dollars (ARRA) \\
\hline Proposed Operating Budget Detail & Actual 2009-10 & Proposed 2010-11 \\
\hline Jobs Saved/Created & & $\$ 1,842,058$ \\
\hline Scholarships & $\$ 1,925,121$ & $\$ 0$ \\
\hline Library Resources & $\$ 0$ & $\$ 0$ \\
\hline Building Repairs/Alterations & $\$ 0$ & $\$ 0$ \\
\hline Motor Vehicles & $\$ 0$ & $\$ 0$ \\
\hline Printing & $\$ 0$ & $\$ 0$ \\
\hline Furniture \& Equipment & $\$ 0$ & $\$ 0$ \\
\hline Information Technology Equipment & $\$ 0$ & $\$ 0$ \\
\hline Financial Aid to Medical Students & $\$ 0$ & $\$ 0$ \\
\hline Other: & $\$ 0$ & $\$ 0$ \\
\hline TOTAL & $\$ 1,925,121$ & $\$ 1,842,058$ \\
\hline
\end{tabular}


STATE UNIVERSITY SYSTEM - 2010 ANNUAL REPORT

Section 2 - Personnel

\section{University of South Florida--St. Petersburg}

\section{Table 2A. Personnel Headcount}

\begin{tabular}{|c|c|c|c|c|c|c|c|c|c|c|}
\hline & \multicolumn{2}{|c|}{ Fall 2005} & \multicolumn{2}{|c|}{ Fall 2006} & \multicolumn{2}{|c|}{ Fall 2007} & \multicolumn{2}{|c|}{ Fall 2008} & \multicolumn{2}{|c|}{ Fall 2009} \\
\hline & FT & PT & FT & PT & FT & PT & FT & PT & FT & PT \\
\hline $\begin{array}{c}\text { Faculty } \\
\text { Tenure/ Tenure-track }\end{array}$ & 73 & 0 & 86 & 0 & 93 & 0 & 87 & 1 & 85 & 0 \\
\hline $\begin{array}{c}\text { Faculty } \\
\text { Non-Tenure Track }\end{array}$ & 36 & 5 & 34 & 5 & 35 & 4 & 26 & 8 & 27 & 9 \\
\hline $\begin{array}{l}\text { Instructors Without } \\
\text { Faculty Status }\end{array}$ & 0 & 0 & 0 & 0 & 0 & 0 & 0 & 0 & 0 & 0 \\
\hline $\begin{array}{c}\text { Graduate Assistants/ } \\
\text { Associates }\end{array}$ & & 24 & & 20 & & 19 & & 20 & & 26 \\
\hline $\begin{array}{c}\text { Executive/ } \\
\text { Administrative/ Managerial }\end{array}$ & 32 & 0 & 33 & 0 & 39 & 4 & 38 & 0 & 35 & 0 \\
\hline Other Professional & 68 & 34 & 78 & 3 & 64 & 6 & 67 & 2 & 67 & 2 \\
\hline Non-Professional & 92 & 1 & 100 & 0 & 109 & 0 & 92 & 4 & 91 & 5 \\
\hline TOTAL PERSONNEL & \multicolumn{2}{|c|}{365} & \multicolumn{2}{|c|}{359} & \multicolumn{2}{|c|}{367} & \multicolumn{2}{|c|}{345} & \multicolumn{2}{|c|}{347} \\
\hline $\begin{array}{l}\text { *Due to a programming con } \\
\text { would be applicable to both } \\
\text { figures will not roll-up to su }\end{array}$ & & & -0 & & & & & & & \\
\hline
\end{tabular}


STATE UNIVERSITY SYSTEM - 2010 ANNUAL REPORT

Section 3 - Enrollment \& Space

University of South Florida--St. Petersburg

Table 3A. University Full-Time Enrollment (FTE)

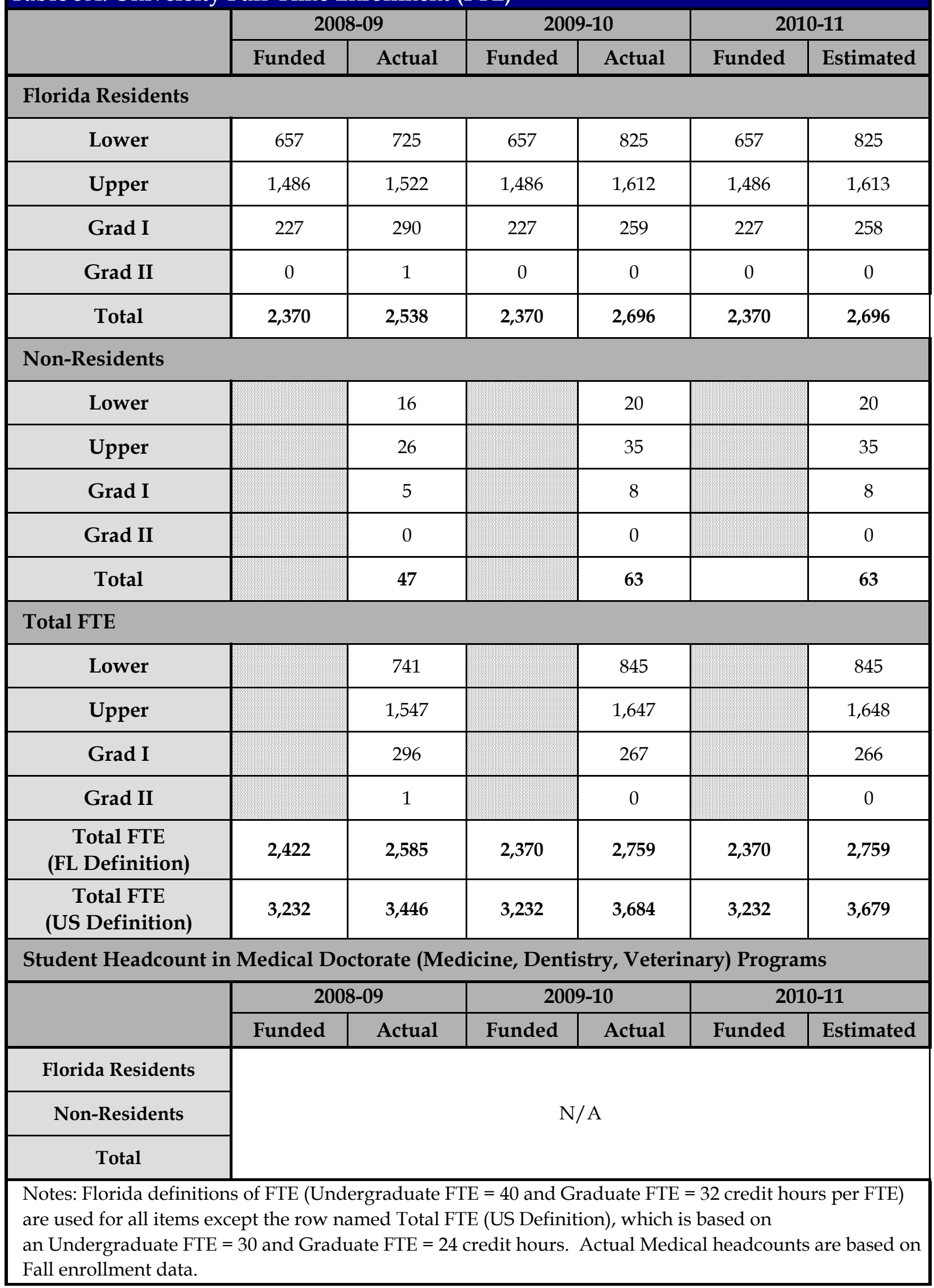


STATE UNIVERSITY SYSTEM - 2010 ANNUAL REPORT

Section 3 - Enrollment \& Space

University of South Florida--St. Petersburg

Table 3B. Enrollment by Location

For each distinct location (main, branch, site, regional campus) with> 150 FTE. Add additional tables for sites, as needed.

SITE: USF St. Petersburg

\begin{tabular}{|c|c|c|c|}
\hline FTE by LEVEL & $\begin{array}{c}\mathbf{2 0 0 8 - 0 9} \\
\text { Actual }\end{array}$ & $\begin{array}{c}\mathbf{2 0 0 9 - 1 0} \\
\text { Actual }\end{array}$ & $\begin{array}{c}\mathbf{2 0 1 0 - 1 1} \\
\text { Estimated }\end{array}$ \\
\hline Lower & 741 & 845 & 845 \\
\hline Upper & 1,547 & 1,647 & 1,648 \\
\hline Grad I & 296 & 267 & 266 \\
\hline Grad II & 1 & 0 & 0 \\
\hline Total & $\mathbf{2 , 5 8 5}$ & $\mathbf{2 , 7 5 9}$ & $\mathbf{2 , 7 5 9}$ \\
\hline
\end{tabular}

*These figures match the enrollment plan submitted earlier this year. 
STATE UNIVERSITY SYSTEM - 2010 ANNUAL REPORT

Section 4 - Undergraduate Education

University of South Florida--St. Petersburg

Table 4A. Baccalaureate Degree Program Changes in AY 2009-2010

\begin{tabular}{|c|c|c|c|c|c|}
\hline $\begin{array}{c}\text { Title of Program } \\
\text { (add more rows as needed) }\end{array}$ & $\begin{array}{c}\text { Six-digit } \\
\text { CIP Code }\end{array}$ & $\begin{array}{c}\text { Degree } \\
\text { Level }\end{array}$ & $\begin{array}{c}\text { Date of } \\
\text { UBOT } \\
\text { Action }\end{array}$ & $\begin{array}{c}\text { Starting } \\
\text { or Ending } \\
\text { Term }\end{array}$ & Comments \\
\hline
\end{tabular}

New Programs

\begin{tabular}{|l|l|l|l|l|} 
N/A & & & & \\
\hline
\end{tabular}

Terminated Programs

\begin{tabular}{|c|l|l|l|l|l|}
\hline N/A & & & & & \\
\hline Suspended Programs & & & & \\
\hline N/A & & & & & \\
\hline
\end{tabular}

New Programs Considered by University But Not Approved 
STATE UNIVERSITY SYSTEM - 2010 ANNUAL REPORT

Section 4 - Undergraduate Education

University of South Florida--St. Petersburg

Table 4B. First-Year Persistence Rates

\begin{tabular}{|c|c|c|c|c|c|}
\hline Term of Entry & 2004 & 2005 & 2006 & 2007 & 2008 \\
\hline $\begin{array}{c}\text { Cohort Size } \\
\text { Full-Time FTIC }\end{array}$ & 169 & 179 & 274 & 233 & 378 \\
\hline From Same University & & & \\
\hline \% Still Enrolled & $66 \%$ & $75 \%$ & $65 \%$ & $73 \%$ & $68 \%$ \\
\hline
\end{tabular}

Table 4C. Federal Definition - Undergraduate Progression and Graduation Rates for Full-Time First-Time-in-College (FTIC) Students

\begin{tabular}{|c|c|c|c|c|c|}
\hline Term of Entry & Fall 2000 & Fall 2001 & Fall 2002 & Fall 2003 & Fall 2004 \\
\hline $\begin{array}{l}\text { Cohort Size } \\
\text { Full-Time FTIC }\end{array}$ & \multicolumn{5}{|c|}{$\begin{array}{l}\text { Parsing of retention/graduation data at the campus-level cannot be completed at } \\
\text { this time. }\end{array}$} \\
\hline \multicolumn{6}{|l|}{6 - Year Rates } \\
\hline \multicolumn{6}{|c|}{ From Same University } \\
\hline$\%$ Graduated & \multirow{3}{*}{\multicolumn{5}{|c|}{$\begin{array}{l}\text { Parsing of retention/graduation data at the campus-level cannot be completed at } \\
\text { this time. }\end{array}$}} \\
\hline \% Still Enrolled & & & & & \\
\hline Success Rate & & & & & \\
\hline \multicolumn{6}{|c|}{$\begin{array}{l}\text { Notes: (1) Cohorts are based on undergraduate students who enter the institution in the Fall term (or Summer } \\
\text { term and continue into the Fall term); (2) Success Rate measures the percentage of an intial cohort of students } \\
\text { who have either graduated or are still enrolled. }\end{array}$} \\
\hline
\end{tabular}




\section{STATE UNIVERSITY SYSTEM - 2010 ANNUAL REPORT \\ Section 4 - Undergraduate Education Data \\ University of South Florida--St. Petersburg}

\section{Table 4D. SUS - Undergraduate Progression and Graduation Rates}

for First-Time-in-College (FTIC) Students

\begin{tabular}{|c|c|c|c|c|c|}
\hline Term of Entry & Fall 2000 & Fall 2001 & Fall 2002 & Fall 2003 & Fall 2004 \\
\hline $\begin{array}{l}\text { Cohort Size } \\
\text { Full- E Part-Time }\end{array}$ & \multicolumn{5}{|c|}{$\begin{array}{c}\text { Parsing of retention/graduation data at the campus-level cannot be completed at } \\
\text { this time. }\end{array}$} \\
\hline \multicolumn{6}{|l|}{4 - Year Rates } \\
\hline \multicolumn{6}{|c|}{ From Same University } \\
\hline$\%$ Graduated & \multirow{2}{*}{\multicolumn{5}{|c|}{$\begin{array}{l}\text { Parsing of retention/graduation data at the campus-level cannot be completed at } \\
\text { this time. }\end{array}$}} \\
\hline \% Still Enrolled & & & & & \\
\hline \multicolumn{6}{|c|}{ From Other SUS Institution } \\
\hline$\%$ Graduated & \multirow{2}{*}{\multicolumn{5}{|c|}{$\begin{array}{c}\text { Parsing of retention/graduation data at the campus-level cannot be completed at } \\
\text { this time. }\end{array}$}} \\
\hline \% Still Enrolled & & & & & \\
\hline \multicolumn{6}{|c|}{ From State University System } \\
\hline$\%$ Graduated & \multirow{3}{*}{\multicolumn{5}{|c|}{$\begin{array}{l}\text { Parsing of retention/graduation data at the campus-level cannot be completed at } \\
\text { this time. }\end{array}$}} \\
\hline \% Still Enrolled & & & & & \\
\hline Success Rate & & & & & \\
\hline \multicolumn{6}{|l|}{6 - Year Rates } \\
\hline \multicolumn{6}{|c|}{ From Same University } \\
\hline$\%$ Graduated & \multirow{2}{*}{\multicolumn{5}{|c|}{$\begin{array}{l}\text { Parsing of retention/graduation data at the campus-level cannot be completed at } \\
\text { this time. }\end{array}$}} \\
\hline \% Still Enrolled & & & & & \\
\hline \multicolumn{6}{|c|}{ From Other SUS Institution } \\
\hline$\%$ Graduated & \multirow{2}{*}{\multicolumn{5}{|c|}{$\begin{array}{l}\text { Parsing of retention/graduation data at the campus-level cannot be completed at } \\
\text { this time. }\end{array}$}} \\
\hline \% Still Enrolled & & & & & \\
\hline \multicolumn{6}{|c|}{ From State University System } \\
\hline$\%$ Graduated & \multirow{3}{*}{\multicolumn{5}{|c|}{$\begin{array}{l}\text { Parsing of retention/graduation data at the campus-level cannot be completed at } \\
\text { this time. }\end{array}$}} \\
\hline$\%$ Still Enrolled & & & & & \\
\hline Success Rate & & & & & \\
\hline \multicolumn{6}{|c|}{$\begin{array}{l}\text { Notes: (1) Cohorts are based on undergraduate students who enter the institution in the Fall term (or Summer } \\
\text { term and continue into the Fall term); (2) Success Rate measures the percentage of an intial cohort of students } \\
\text { who have either graduated or are still enrolled. }\end{array}$} \\
\hline
\end{tabular}




\section{STATE UNIVERSITY SYSTEM - 2010 ANNUAL REPORT \\ Section 4 - Undergraduate Education Data \\ University of South Florida--St. Petersburg}

\section{Table 4E. SUS - Undergraduate Progression and Graduation Rates}

for AA Transfer Students

\begin{tabular}{|c|c|c|c|c|c|}
\hline Term of Entry & Fall 2002 & Fall 2003 & Fall 2004 & Fall 2005 & Fall 2006 \\
\hline $\begin{array}{c}\text { Cohort Size } \\
\text { Full- E Part-Time }\end{array}$ & Parsing of retention/graduation data at the campus-level cannot be completed at \\
this time.
\end{tabular}

\section{2 - Year Rates}

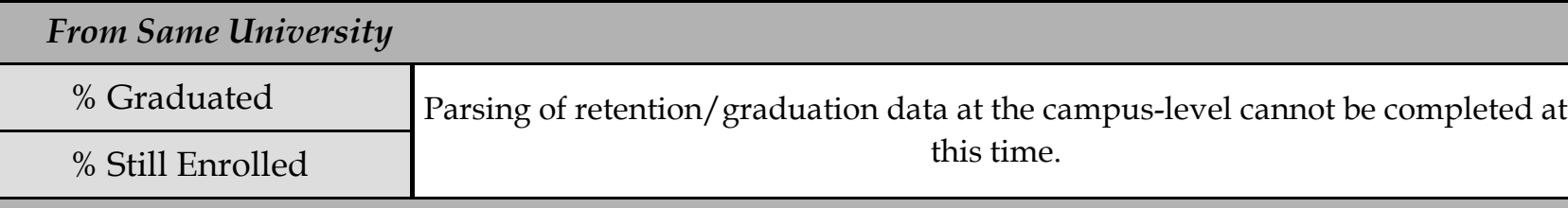

\section{From Other SUS Institution}

\begin{tabular}{|c|c|}
\hline$\%$ Graduated & Parsing of retention/graduation data at the campus-level cannot be completed at \\
this time.
\end{tabular}

\section{From State University System}

$\%$ Graduated

$\%$ Still Enrolled

Parsing of retention/graduation data at the campus-level cannot be completed at Success Rate

\section{4 - Year Rates}

\section{From Same University}

$\%$ Graduated

$\%$ Still Enrolled
Parsing of retention/graduation data at the campus-level cannot be completed at this time.

\section{From Other SUS Institution}

$\%$ Graduated

$\%$ Still Enrolled
Parsing of retention/graduation data at the campus-level cannot be completed at this time.

\section{From State University System}

$\%$ Graduated

$\%$ Still Enrolled

Success Rate
Parsing of retention/graduation data at the campus-level cannot be completed at this time.

Notes: (1) Cohorts are based on undergraduate students who enter the institution in the Fall term (or Summer term and continue into the Fall term); (2) Success Rate measures the percentage of an intial cohort of students who have either graduated or are still enrolled. 


\section{STATE UNIVERSITY SYSTEM - 2010 ANNUAL REPORT \\ Section 4 - Undergraduate Education Data \\ University of South Florida--St. Petersburg}

Table 4F. SUS - Undergraduate Progression and Graduation Rates

for Other Transfer Students

\begin{tabular}{|c|c|c|c|c|c|}
\hline Term of Entry & Fall 2001 & Fall 2002 & Fall 2003 & Fall 2004 & Fall 2005 \\
\hline $\begin{array}{l}\text { Cohort Size } \\
\text { Full- E Part-Time }\end{array}$ & \multicolumn{5}{|c|}{$\begin{array}{l}\text { Parsing of retention/graduation data at the campus-level cannot be completed at } \\
\text { this time. }\end{array}$} \\
\hline \multicolumn{6}{|l|}{5 - Year Rates } \\
\hline \multicolumn{6}{|c|}{ From Same University } \\
\hline$\%$ Graduated & \multirow{2}{*}{\multicolumn{5}{|c|}{$\begin{array}{l}\text { Parsing of retention/graduation data at the campus-level cannot be completed at } \\
\text { this time. }\end{array}$}} \\
\hline \% Still Enrolled & & & & & \\
\hline \multicolumn{6}{|c|}{ From Other SUS Institution } \\
\hline$\%$ Graduated & \multirow{2}{*}{\multicolumn{5}{|c|}{$\begin{array}{l}\text { Parsing of retention/graduation data at the campus-level cannot be completed at } \\
\text { this time. }\end{array}$}} \\
\hline \% Still Enrolled & & & & & \\
\hline \multicolumn{6}{|c|}{ From State University System } \\
\hline$\%$ Graduated & \multirow{3}{*}{\multicolumn{5}{|c|}{$\begin{array}{l}\text { Parsing of retention/graduation data at the campus-level cannot be completed at } \\
\text { this time. }\end{array}$}} \\
\hline \% Still Enrolled & & & & & \\
\hline Success Rate & & & & & \\
\hline \multicolumn{6}{|c|}{$\begin{array}{l}\text { Notes: (1) Cohorts are based on undergraduate students who enter the institution in the Fall term (or Summer } \\
\text { term and continue into the Fall term); (2) Success Rate measures the percentage of an intial cohort of students } \\
\text { who have either graduated or are still enrolled. }\end{array}$} \\
\hline
\end{tabular}

\section{Table 4G. Baccalaureate Degrees Awarded}

\begin{tabular}{|l|c|c|c|c|c|}
\hline & $2005-2006$ & $2006-2007$ & $2007-2008$ & $2008-2009$ & $2009-2010$ \\
\hline Baccalaureate Degrees & 634 & 647 & 668 & 657 & 681 \\
\hline
\end{tabular}

\section{Table 4H. Baccalaureate Degrees Awarded in Areas of Strategic Emphasis}

\begin{tabular}{|c|c|c|c|c|c|}
\hline & 2005-2006 & 2006-2007 & $2007-2008$ & 2008-2009 & 2009-2010 \\
\hline Education & 16 & 18 & 12 & 15 & 14 \\
\hline Health Professions & 0 & 0 & 0 & 0 & 0 \\
\hline $\begin{array}{l}\text { Science, Technology, } \\
\text { Engineering, and Math }\end{array}$ & 42 & 26 & 30 & 30 & 32 \\
\hline $\begin{array}{c}\text { Security and } \\
\text { Emergency Services }\end{array}$ & 45 & 35 & 39 & 38 & 43 \\
\hline Globalization & 32 & 29 & 41 & 37 & 35 \\
\hline $\begin{array}{l}\text { TOTAL: Areas of } \\
\text { Strategic Emphasis }\end{array}$ & 135 & 108 & 122 & 120 & 124 \\
\hline
\end{tabular}




\section{STATE UNIVERSITY SYSTEM - 2010 ANNUAL REPORT \\ Section 4 - Undergraduate Education Data \\ University of South Florida--St. Petersburg}

\section{Table 4I. Baccalaureate Degrees Awarded to Underrepresented Groups}

\begin{tabular}{|c|c|c|c|c|c|}
\hline & 2005-2006 & 2006-2007 & 2007-2008 & $\begin{array}{c}\text { 2008-2009 } \\
\text { BASELINE YEAR }\end{array}$ & 2009-2010 \\
\hline \multicolumn{6}{|c|}{ Non-Hispanic Black Students } \\
\hline $\begin{array}{c}\text { Number of } \\
\text { Baccalaureate Degrees }\end{array}$ & 35 & 38 & 35 & $\begin{array}{c}45 \\
\text { Maintain* } \\
\end{array}$ & 36 \\
\hline $\begin{array}{c}\text { Percentage of All } \\
\text { Baccalaureate Degrees }\end{array}$ & $5.8 \%$ & $6.2 \%$ & $5.4 \%$ & $\begin{array}{c}7 \% \\
\text { Maintain* }\end{array}$ & $5.4 \%$ \\
\hline \multicolumn{6}{|l|}{ Hispanic Students } \\
\hline $\begin{array}{c}\text { Number of } \\
\text { Baccalaureate Degrees }\end{array}$ & 39 & 29 & 45 & $\begin{array}{c}52 \\
\text { Increase }^{*}\end{array}$ & 56 \\
\hline $\begin{array}{c}\text { Percentage of All } \\
\text { Baccalaureate Degrees }\end{array}$ & $6.4 \%$ & $4.7 \%$ & $7.0 \%$ & $\begin{array}{c}8.1 \% \\
\text { Increase }^{*}\end{array}$ & $8.4 \%$ \\
\hline \multicolumn{6}{|l|}{ PELL-Grant Recipients } \\
\hline $\begin{array}{c}\text { Number of } \\
\text { Baccalaureate Degrees* }\end{array}$ & 244 & 239 & 230 & $\begin{array}{c}243 \\
\text { Maintain* }\end{array}$ & 274 \\
\hline $\begin{array}{c}\text { Percentage of All } \\
\text { Baccalaureate Degrees }\end{array}$ & $40.3 \%$ & $40.0 \%$ & $35.7 \%$ & $\begin{array}{c}37.9 \% \\
\text { Maintain* }\end{array}$ & $40.4 \%$ \\
\hline
\end{tabular}

Note: Pell-Grant recipients are defined as those students who have received a Pell-Grant Within 6 Years of Graduation. This does not include degrees awarded to students whose race/ethnicity code is missing (or not reported) or for students who are non-resident aliens. Note*: Directional goals for the 2012-13 year as reported in the 2010 University Workplan.

*Due to methodology changes in this data metric, campus-level figures may not roll up to the system numbers.

\section{Table 4J. Baccalaureate Completion Without Excess Credit Hours}

\begin{tabular}{|c|c|c|c|c|c|}
\hline & $2005-2006$ & $2006-2007$ & $2007-2008$ & $2008-2009$ & $2009-2010$ \\
\hline $\begin{array}{c}\text { \% of Total Baccalaureate } \\
\text { Degrees Awarded Within } \\
\mathbf{1 1 0 \%} \begin{array}{c}\text { of Hours Required } \\
\text { for Degree }\end{array}\end{array}$ & N/A & N/A & $52.3 \%$ & $48.6 \%$ & $47.8 \%$ \\
\hline
\end{tabular}

\section{Table 4K. Undergraduate Course Offerings}

\begin{tabular}{|c|c|c|c|c|c|}
\hline & Fall 2005 & Fall 2006 & Fall 2007 & Fall 2008 & Fall 2009 \\
\hline $\begin{array}{c}\text { Number of } \\
\text { Course Sections }\end{array}$ & 376 & 390 & 378 & 342 & 340 \\
\hline \multicolumn{2}{|c|}{ Percentage of Undergraduate Course Sections by Class Size } \\
\hline $\begin{array}{c}\text { Fewer than } 30 \\
\text { Students }\end{array}$ & $59.0 \%$ & $60.5 \%$ & $58.5 \%$ & $54.7 \%$ & $51.8 \%$ \\
\hline $\begin{array}{c}\mathbf{3 0} \text { to } \mathbf{4 9} \\
\text { Students }\end{array}$ & $35.6 \%$ & $33.9 \%$ & $35.9 \%$ & $34.2 \%$ & $39.4 \%$ \\
\hline $\begin{array}{c}50 \text { to } 99 \\
\text { Students }\end{array}$ & $5.4 \%$ & $5.6 \%$ & $5.6 \%$ & $10.8 \%$ & $8.5 \%$ \\
\hline $\begin{array}{c}\text { 100 or More } \\
\text { Students }\end{array}$ & $0.0 \%$ & $0.0 \%$ & $0.0 \%$ & $0.0 \%$ & $0.3 \%$ \\
\hline
\end{tabular}




\section{STATE UNIVERSITY SYSTEM - 2010 ANNUAL REPORT}

Section 4 - Undergraduate Education Data

\section{University of South Florida--St. Petersburg}

Table 4L. Faculty Teaching Undergraduates

\begin{tabular}{|c|c|c|c|c|c|}
\hline & $2005-2006$ & $2006-2007$ & $2007-2008$ & $2008-2009$ & $2009-2010$ \\
\hline Percentage of Credit Hours Taught by: & $64.7 \%$ & $67.4 \%$ & $71.1 \%$ & $67.9 \%$ & $68.7 \%$ \\
\hline Faculty & $34.7 \%$ & $31.6 \%$ & $27.8 \%$ & $31.4 \%$ & $30.8 \%$ \\
\hline Adjunct Faculty & $0.1 \%$ & $0.7 \%$ & $0.2 \%$ & $0.5 \%$ & $0.3 \%$ \\
\hline Other Instructors & $0.5 \%$ & $0.3 \%$ & $1.0 \%$ & $0.2 \%$ & $0.2 \%$ \\
\hline
\end{tabular}

Note: The definition of faculty varies for Tables $4 \mathrm{~L}, 4 \mathrm{M}$ and $4 \mathrm{~N}$. For Faculty Teaching Undergraduates, the definition of faculty is based on pay plans 01,02 , and 22 .

\section{Table 4M. Undergraduate Instructional Faculty Compensation}

\begin{tabular}{|c|c|c|c|c|c|}
\hline $\begin{array}{c}\text { Average Salary and } \\
\text { Benefits for Faculty Who } \\
\text { Teach at Least One } \\
\text { Undergraduate Course }\end{array}$ & Fall 2005 & Fall 2006 & Fall 2007 & Fall 2008 & Fall 2009 \\
\hline $\begin{array}{l}\text { Und,933 } \\
\text { Note: The definition of faculty varies for Tables 4L, 4M and 4N. For Undergraduate Instructional Faculty } \\
\text { Compensation, the definition of faculty is based on pay plan 22. }\end{array}$ & $\$ 83,146$ & $\$ 89,120$ & $\$ 91,252$ & $\$ 93,114$ \\
\hline
\end{tabular}

\section{Table 4N. Student/Faculty Ratio}

\begin{tabular}{|l|c|c|c|c|c|}
\hline & $2005-2006$ & $2006-2007$ & $2007-2008$ & $2008-2009$ & $2009-2010$ \\
\hline Student-to-Faculty Ratio & 17 & 19 & 19 & 22 & 24 \\
\hline
\end{tabular}

Note: The definition of faculty varies for Tables $4 \mathrm{~L}, 4 \mathrm{M}$ and $4 \mathrm{~N}$. For Student/Faculty Ratio, the definition of faculty is consistent with Common Data Set reporting (which counts full-time equivalent instructional faculty as full-time faculty plus $1 / 3$ part-time faculty). 
STATE UNIVERSITY SYSTEM - 2010 ANNUAL REPORT

Section 4 - Undergraduate Education Data

University of South Florida--St. Petersburg

Table 4O. Professional Licensure Exams - Undergraduate Programs

\begin{tabular}{|l|c|c|c|c|c|}
\hline & 2005 & 2006 & 2007 & 2008 & 2009 \\
\hline Nursing: National Council Licensure Examination for Registered Nurses \\
\hline Examinees \\
\cline { 1 - 1 } Pass Rate \\
\hline National Benchmark
\end{tabular}

\begin{tabular}{|c|c|c|c|}
\hline Table 4P. Tuition Differential Fee & $2008-2009$ & $2009-2010$ & $\begin{array}{c}\text { 2010-2011 } \\
\text { Projected }\end{array}$ \\
\hline $\begin{array}{c}\text { Total Revenues Generated } \\
\text { By the Tuition Differential }\end{array}$ & -- & $\$ 409,066$ & $\$ 1,010,274$ \\
\hline $\begin{array}{c}\text { Unduplicated Count of Students } \\
\text { Receiving Financial Aid Award } \\
\text { Funded by Tuition Differential Revenues }\end{array}$ & -- & 116 & \\
\hline $\begin{array}{c}\text { Average Amount of Awards } \\
\text { Funded by Tuition Differential Revenues } \\
\text { (per student receiving an award) }\end{array}$ & -- & $\$ 904$ & \\
\hline $\begin{array}{c}\text { Number of Students Eligible for FSAG } \\
\text { Number of FSAG-Eligible Students Receiving } \\
\text { a Waiver of the Tuition Differential }\end{array}$ & -- & 555 & \\
\hline $\begin{array}{c}\text { Value of Tuition Differential Waivers } \\
\text { Provided to FSAG-Eligible Students }\end{array}$ & -- & 0 & \\
\hline $\begin{array}{l}\text { Report on the success of the tuition differential in achieving the articulated purpose. } \\
\text { Include an update on any performance measures that were specified in the Board of }\end{array}$ \\
$\quad$ Governors-approved tuition differential proposal. \\
\hline
\end{tabular}


The institution proposed to use the Tuition Differential funds to:

- Support ongoing commitments to faculty and staff hired in 2009-10.

o Two faculty members in key program of strategic importance

o One new freshman advisor

o New pre-health advisor (partially funded with tuition differential funds)

o One new staff member in Office of Registration and Records

- Support two additional new faculty hires in the sciences, specifically biochemistry, genetics, to provide badly needed courses for USFSP pre-health/health sciences students. Currently students must take these courses elsewhere. In addition, funds will be used to support the new courses taught in the first year.

- Support for additional academic advisors, support staff, and tutors. The current student:advisor ratio is 487:1. USFSP's student demographic and academic profile generally indicates that more advising help as well as academic support are needed. The USFSP Academic Success Center is one of only three at SUS institutions that is accredited by the College Reading and Learning Association.

- Additional support for the Office of Registration and Records support staff to enhance student services and provide extended hours.

\section{Progress is as follows:}

- Searches for the science faculty are underway.

- An additional staff member has been hired for the Office of Registration and Records to provide increased service levels to students and other institutional constituencies.

- An additional advisor search is nearly completed (when hired will reduce USFSP student:advisor ratio to about 430:1.)

- Staff member has been hired in the Office of Academic Advising to provide extended hours of operation.

- Funds have been provided for technology upgrades for the Office of Registration and Records.

- Funds have been allocated to the Academic Success Center for additional tutors. The Center was able to serve over 900 students in 2009-10, up from about 800 the previous year.

Detailed expenditures of the revenues generated by the tuition differential will be captured in the Operating Budget submission each August. 
STATE UNIVERSITY SYSTEM - 2010 ANNUAL REPORT

Section 5 - Graduate Education Data

University of South Florida--St. Petersburg

Table 5A. GraduateDegree Programs Changes in AY 2009-2010

\begin{tabular}{|c|c|c|c|c|c|}
$\begin{array}{c}\text { Title of Program } \\
\text { (add more rows as needed) }\end{array}$ & $\begin{array}{c}\text { Six-digit } \\
\text { CIP Code }\end{array}$ & $\begin{array}{c}\text { Degree } \\
\text { Level }\end{array}$ & $\begin{array}{c}\text { Date of } \\
\text { UBOT } \\
\text { Action }\end{array}$ & $\begin{array}{c}\text { Starting } \\
\text { or Ending } \\
\text { Term }\end{array}$ & $\begin{array}{c}\text { Date of } \\
\text { Board of } \\
\text { Governors } \\
\text { Action }\end{array}$ \\
\hline
\end{tabular}

Comments

New Programs

$\mathrm{N} / \mathrm{A}$

\begin{tabular}{|l|l|}
\hline & \\
\hline
\end{tabular}

(n)

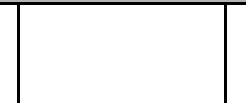

Terminated Programs

$$
\mathrm{N} / \mathrm{A}
$$

\begin{tabular}{|l|l|l|}
\hline & & \\
\hline
\end{tabular}

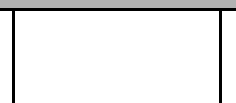

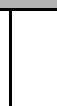

Suspended Programs

$$
\mathrm{N} / \mathrm{A}
$$

New Programs Considered by University But Not Approved 
STATE UNIVERSITY SYSTEM - 2010 ANNUAL REPORT

Section 5 - Graduate Education Data

University of South Florida--St. Petersburg

Table 5B. Graduate Degrees Awarded

\begin{tabular}{|c|c|c|c|c|c|}
\hline & 2005-2006 & 2006-2007 & 2007-2008 & 2008-2009 & 2009-2010 \\
\hline Master's and Specialist & 120 & 144 & 125 & 158 & 148 \\
\hline Research Doctoral & 4 & 0 & 0 & 0 & 0 \\
\hline Professional Doctoral & 0 & 0 & 0 & 0 & 0 \\
\hline a) Medicine & 0 & 0 & 0 & 0 & 0 \\
\hline b) Law & 0 & 0 & 0 & 0 & 0 \\
\hline c) Pharmacy & 0 & 0 & 0 & 0 & 0 \\
\hline $\begin{array}{l}\text { Research/ Professional } \\
\text { Doctoral, Combined }\end{array}$ & 4 & 0 & 0 & 0 & 0 \\
\hline \multicolumn{6}{|c|}{$\begin{array}{l}\text { Note: The total number of Professional Doctoral degrees includes other programs that are not } \\
\text { specifically identified in lines } a, b \text {, and c. }\end{array}$} \\
\hline & $2005-2006$ & 2006-2007 & 2007-2008 & 2008-2009 & 2009-2010 \\
\hline $\begin{array}{c}\text { Education } \\
\text { Critical Shortage Areas }\end{array}$ & 38 & 33 & 41 & 54 & 36 \\
\hline Health Professions & 0 & 0 & 0 & 0 & 0 \\
\hline $\begin{array}{l}\text { Science, Technology, } \\
\text { Engineering, and Math }\end{array}$ & 0 & 0 & 0 & 1 & 2 \\
\hline $\begin{array}{c}\text { Security and } \\
\text { Emergency Services }\end{array}$ & 0 & 0 & 0 & 0 & 0 \\
\hline Globalization & 0 & 0 & 0 & 0 & 0 \\
\hline TOTAL & 38 & 33 & 41 & 55 & 38 \\
\hline
\end{tabular}


STATE UNIVERSITY SYSTEM - 2010 ANNUAL REPORT

Section 5 - Graduate Education Data

University of South Florida--St. Petersburg

Table 5D. Professional Licensure Exams - Graduate Programs

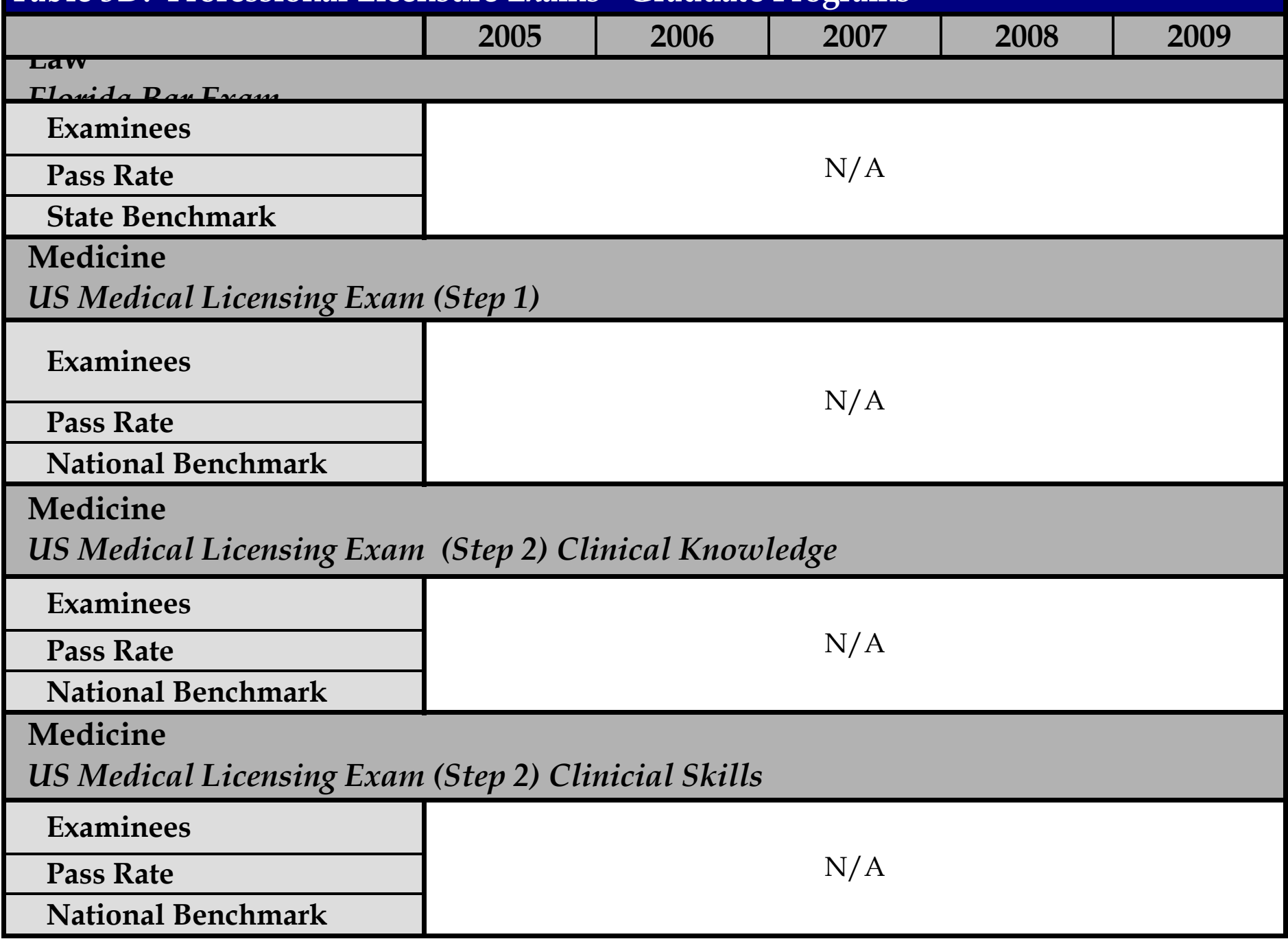

Note: All licensure data is based on first-time examinees. 
STATE UNIVERSITY SYSTEM - 2010 ANNUAL REPORT

Section 5 - Graduate Education Data

University of South Florida--St. Petersburg

Table 5D. Professional Licensure Exams - Graduate Programs

\begin{tabular}{|c|c|c|c|c|c|}
\hline & 2005 & 2006 & 2007 & 2008 & 2009 \\
\hline \multicolumn{6}{|c|}{$\begin{array}{l}\text { Dentistry } \\
\text { National Dental Board Exam (Part 1) }\end{array}$} \\
\hline Examinees & & & \multirow{3}{*}{$\mathrm{N} / \mathrm{A}$} & & \\
\hline Pass Rate & & & & & \\
\hline National Benchmark & & & & & \\
\hline \multicolumn{6}{|c|}{$\begin{array}{l}\text { Dentistry } \\
\text { National Dental Board Exam (Part 2) }\end{array}$} \\
\hline Examinees & & & \multirow{3}{*}{ N/A } & & \\
\hline Pass Rate & & & & & \\
\hline National Benchmark & & & & & \\
\hline \multicolumn{6}{|c|}{$\begin{array}{l}\text { Veterinary Medicine } \\
\text { North American Veterinary Licensing Exam }\end{array}$} \\
\hline Examinees & & & \multirow{3}{*}{ N/A } & & \\
\hline Pass Rate & & & & & \\
\hline National Benchmark & & & & & \\
\hline \multicolumn{6}{|c|}{$\begin{array}{l}\text { Pharmacy } \\
\text { North American Pharmacist Licensure Exam }\end{array}$} \\
\hline Examinees & & & \multirow{3}{*}{$\mathrm{N} / \mathrm{A}$} & & \\
\hline Pass Rate & & & & & \\
\hline National Benchmark & & & & & \\
\hline
\end{tabular}

Note: All licensure data is based on first-time examinees. 


\begin{tabular}{|c|c|c|c|c|c|}
\hline \multicolumn{6}{|c|}{$\begin{array}{l}\text { STATE UNIVERSITY SYSTEM - } 2010 \text { ANNUAL REPORT } \\
\text { Section } 6 \text { - Research and Economic Development }\end{array}$} \\
\hline \multicolumn{6}{|c|}{ University of South Florida--St. Petersburg } \\
\hline \multicolumn{6}{|c|}{ Table 6A. Research and Development } \\
\hline & 2004-2005 & 2005-2006 & 2006-2007 & 2007-2008 & 2008-2009 \\
\hline \multicolumn{6}{|c|}{ R\&D Awards (includes non-Science \& Engineering awards) } \\
\hline $\begin{array}{l}\text { Federally Funded Awards } \\
\text { (Thousand \$) }\end{array}$ & \multirow{2}{*}{\multicolumn{4}{|c|}{ Historical data not available at this time by campus. }} & $\$ 324$ \\
\hline $\begin{array}{l}\text { Total Awards } \\
\text { (Thousand \$) }\end{array}$ & & & & & $\$ 479$ \\
\hline \multicolumn{6}{|c|}{ R\&D Expenditures (includes non-Science \& Engineering expenditures) } \\
\hline $\begin{array}{l}\text { Federally Financed Expenditures } \\
\text { (Thousand \$) }\end{array}$ & \multirow{3}{*}{\multicolumn{5}{|c|}{$\begin{array}{l}\text { Development/Research data is a USF system-wide function. Consolidated system } \\
\text { data is only available at this time. }\end{array}$}} \\
\hline $\begin{array}{l}\text { Total Expenditures } \\
\text { (Thousand \$) }\end{array}$ & & & & & \\
\hline $\begin{array}{l}\text { Total R\&D Expenditures } \\
\text { Per Full-Time, Tenured, } \\
\text { Tenure-Earning Faculty Member } \\
\text { (\$) }\end{array}$ & & & & & \\
\hline \multicolumn{6}{|c|}{ Technology Transfer (as reported to AUTM) } \\
\hline Invention Disclosures & \multirow{6}{*}{\multicolumn{5}{|c|}{ Data only applicable for USF System and Tampa. }} \\
\hline Total U.S. Patents Issued & & & & & \\
\hline $\begin{array}{l}\text { Patents Issued Per 1,000 Full- } \\
\text { Time, Tenure and Tenure- } \\
\text { Earning Faculty }\end{array}$ & & & & & \\
\hline $\begin{array}{l}\text { Total Number of Licenses/ } \\
\text { Options Executed }\end{array}$ & & & & & \\
\hline $\begin{array}{l}\text { Total Licensing Income } \\
\text { Received (\$) }\end{array}$ & & & & & \\
\hline $\begin{array}{l}\text { Total Number of Start-Up } \\
\text { Companies }\end{array}$ & & & & & \\
\hline
\end{tabular}


STATE UNIVERSITY SYSTEM - 2010 ANNUAL REPORT

Section 6 - Research and Economic Development

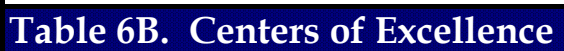

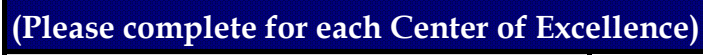

\section{Name of Center:}

Year Created:

\section{N/A}

Cumulative

(since inception

to June 2010)
Fiscal Year 2009-10

\section{Research Effectiveness}

Only include data for activities directly associated with the Center. Do not include the non-Center activities for faculty who are associated with the Center.

Number of Competitive Grants Applied For

Value of Competitive Grants Applied For (\$)

Number of Competitive Grants Received

Value of Competitive Grants Received (\$)

Total Research Expenditures (\$)

Number of Publications in Refereed Journals From Center Research

Number of Invention Disclosures

Number of Licenses/Options Executed

Licensing Income Received (\$)

\section{Collaboration Effectiveness}

Only report on relationships that include financial or in-kind support.

Collaborations with Other Postsecondary Institutions

Collaborations with Private Industry

Collaborations with K-12 Education Systems/Schools

Undergraduate and Graduate Students Supported with Center Funds

Economic Development Effectiveness

Start-Up companies with a physical presence, or employees, in Florida

Jobs Created By Start-Up Companies Associated with the Center

Specialized Industry Training and Education

Private-sector Resources Used to Support the Center's Operations

Narrative Comments [Most Recent Year]

(Limit to a maximum of $1 / 2$ page per center)

Insert additional pages, as needed for additional Centers. 


\begin{tabular}{|c|c|c|c|c|c|}
\hline \multicolumn{6}{|c|}{$\begin{array}{l}\text { STATE UNIVERSITY SYSTEM - } 2010 \text { ANNUAL REPORT } \\
\text { Section } 6 \text { - Research and Economic Development }\end{array}$} \\
\hline \multicolumn{6}{|c|}{ University of South Florida--St. Petersburg } \\
\hline \multicolumn{6}{|c|}{ Table 6C. State University Research Commercialization Assistance Grants } \\
\hline \multirow{2}{*}{\multicolumn{4}{|c|}{ Project Name by Type of Grant }} & \multicolumn{2}{|c|}{ Cumulative } \\
\hline & & & & AWARDS & EXPENDITURES \\
\hline \multicolumn{6}{|l|}{ Phase I Grants } \\
\hline \multicolumn{4}{|l|}{+2} & $\$ 0$ & $\$ 0$ \\
\hline \multirow{2}{*}{\multicolumn{4}{|c|}{ 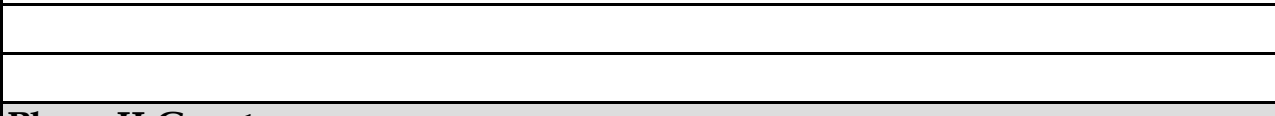 }} & $\$ 0$ & $\$ 0$ \\
\hline & & & & $\$ 0$ & $\$ 0$ \\
\hline \multicolumn{4}{|l|}{ Phase II Grants } & & \\
\hline \multicolumn{4}{|l|}{+2} & $\$ 0$ & $\$ 0$ \\
\hline \multirow{2}{*}{\multicolumn{4}{|c|}{ 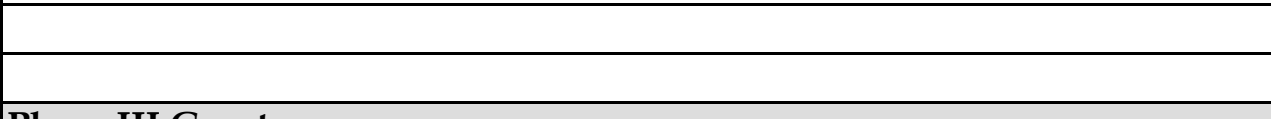 }} & $\$ 0$ & $\$ 0$ \\
\hline & & & & $\$ 0$ & $\$ 0$ \\
\hline \multicolumn{4}{|l|}{ Phase III Grants } & & \\
\hline \multirow{3}{*}{\multicolumn{4}{|c|}{+2}} & $\$ 0$ & $\$ 0$ \\
\hline & & & & $\$ 0$ & $\$ 0$ \\
\hline & & & & $\$ 0$ & $\$ 0$ \\
\hline \multicolumn{4}{|l|}{ Total for all SURCAG Grants } & $\$ 0$ & $\$ 0$ \\
\hline \multicolumn{6}{|l|}{ Narrative Comments } \\
\hline \multirow{2}{*}{\multicolumn{6}{|c|}{$\begin{array}{l}\text { For each project, provide a brief update on: (1) the project's progress to } \\
\text { and (2) the project's return on investment for the university and state. I } \\
\text { update on the project's ability to generate sufficient revenues to sustain } \\
\text { Table 6D. 21st Century World Class Scholars Program }\end{array}$}} \\
\hline & & & & & \\
\hline \multirow[b]{2}{*}{$\begin{array}{l}\text { World Class Scholar(s) } \\
\text { and Field }\end{array}$} & \multicolumn{2}{|c|}{ Grant Dollars } & \multicolumn{3}{|c|}{$\begin{array}{l}\text { Report the cumulative activity } \\
\text { since each scholar's award. }\end{array}$} \\
\hline & $\begin{array}{c}\text { Amount } \\
\text { Awarded } \\
\text { (Thousand \$) }\end{array}$ & $\begin{array}{l}\text { Cumulative } \\
\text { Amount } \\
\text { Expended } \\
\text { (Thousand \$) }\end{array}$ & $\begin{array}{c}\text { External } \\
\text { Research } \\
\text { Awards } \\
\text { (Thousand \$) }\end{array}$ & $\begin{array}{l}\text { Patents } \\
\text { Filed / } \\
\text { Issued }\end{array}$ & $\begin{array}{l}\text { Licensing } \\
\text { Revenues } \\
\text { Generated } \\
\quad(\$)\end{array}$ \\
\hline & & & & & \\
\hline & & & & & \\
\hline & & & & & \\
\hline TOTAL for all Scholars & $\$ 0$ & $\$ 0$ & $\$ 0$ & 0 & $\$ 0$ \\
\hline Narrative Comments & & & & & \\
\hline
\end{tabular}

